\title{
Keefektifan Flexible Learning dalam Menumbuhkan Self-Regulated Learning dan Hasil Belajar Mahasiswa PGSD
}

\author{
Mawardi \\ mawardi@staff.uksw.edu \\ Program Studi PGSD, FKIP, Universitas Kristen Satya Wacana \\ The Effectiveness of Flexible Learning to Fostering Self-Regulated Learning and Learning \\ Outcomes of PGSD Students
}

\begin{abstract}
Online learning using the Flexible Learning (Flearn) Learning Management System (LMS) at SWCU has been running for 17 years. To ensure Flearn's effectiveness, empirical evidence is needed, so this study aims to: 1) determine whether the level of student Self-regulated Learning (SRL) in learning using Flearn is higher than learning using Google Classrom (GC), and 2) knowing whether the level of learning outcomes mediated by the student's SRL level were higher than learning using GC. The type of research used to determine the attainment of this goal is the type of experiment using the Matching-only model Pretest-posttest Control Group design and Factorial design. Participants in this experiment involved 74 people, with details of 36 students and 1 lecturer as the 1st experimental group and 36 students and 1 lecturer as the control group (experiment 2). The experimental group 1 used Flearn, while the experimental group 2 used GC. The research instrument used test questions to measure student learning outcomes variables and SRL scale rubric to measure students' SRL level. The data analysis technique used the Independent Sample t-Test and ANCOVA technique. The results showed the following findings: 1) the level of student SRL in learning using Flearn was significantly higher than learning using GC, 2) the level of student learning outcomes mediated by the student SRL level was significantly higher than learning using GC.
\end{abstract}

Keywords: Flearn, Self-Regulated Learning, Google Classroom

\section{Article Info}

Received date: 11 September 2020 Revised date: 21 September 2020 Accepted date: 24 September 2020

\section{PENDAHULUAN}

Kementerian Pendidikan dan Kebudayaan (Kemendikbud) bersama Gugus Tugas Percepatan Penanganan Covid-19, Kementerian Koordinator Pembangunan Manusia dan Kebudayaan (Kemenko PMK), Kementerian Agama (Kemenag), Kementerian Kesehatan (Kemenkes), Kementerian Dalam Negeri (Kemendagri), Badan Nasional Penanggulangan Bencana (BNPB), dan Komisi X DPR RI mengumumkan Keputusan Bersama Empat Kementerian tentang Panduan Penyelenggaraan Pembelajaran pada Tahun Akademik Baru di Masa Pandemi Corona Virus Disease (Senin $(15 / 06 / 2020)$. Isi pengumuman tersebut adalah sebuah rambu-rambu pembelajaran pada masa pandemi Covid-19, di mana pembelajaran yang memprioritaskan kesehatan dan keselamatan peserta didik, pendidik, tenaga kependidikan, keluarga, dan masyarakat, tidak bisa lain adalah pembelajaran daring atau online. Dari sumber yang berbeda menyatakan bahwa pembelajaran daring sering disepadankan dengan istilah: 1) online learning (belajar online), 2) internet learning (belajar melalui internet), 3) distributed learning (belajar secara terdistribusi), 4) networked learning (belajar secara berjaringan), 5) telelearning (belajar jarak jauh), 6) virtual learning (belajar secara maya), 7) computer-assisted learning (belajar berbantuan komputer), 8) web-based learning (belajar berbasis web), serta 9) distance learning (belajar jarak jauh). Dengan demikian terdapat beragam batasan atau definisi tentang pembelajaran daring, sehingga tidak memungkinkan memberikan batasan yang berlaku umum, karena para ahli mendefinisikan pembelajaran daring sesuai sudut pandangnya. Namun ada persamaannya, yaitu semua mengacu pada pembelajaran menggunakan media komputer sebagai media pembelajaran (Mawardi, 2011; 2014) 
Salah satu kompetensi pedagogik yang harus dimiliki oleh seorang dosen adalah kemampuan mendesain pembelajaran dengan baik. Pembelajaran yang didesain dengan baik akan efektif mencapai tujuan pembelajaran yang telah ditetapkan. Lebih-lebih pada masa pandemi Covid-19 ini para dosen ditantang untuk merancang pembelajaran daring secara inovatif. Kualitas rancangan pembelajaran daring itu sendiri ditentukan oleh kemampuan dosen dalam mempersiapkan komponen-komponen pembelajaran dan mengintegrasikannya dengan baik (Clark \& Mayer, 2008: 7; UU Guru dan Dosen, 2005).

Komponen-komponen utama kompetensi pedagogik mencakup kemampuan merancang tujuan, materi, strategi dan media serta evaluasi pembelajaran. Dirjen Dikti, dalam rangka memberikan panduan bagi para dosen untuk merancang pembelajaran dengan baik, mengeluarkan panduan Sistem Penjaminan Mutu Pendidikan Tinggi (SPM-PT). Pertanyaan reflektif dalam panduan SPM-PT dapat digunakan oleh para dosen dalam merancang pembelajarannya. Pertanyaan-pertanyaan reflektif itu meliputi: apa learning outcomes yang ingin dicapai?, bagaimana kompleksitas capaian hasil pembelajarannya?, apakah memerlukan keterampilan tertentu?, apakah materi matakuliah berupa fakta, konsep, hukum atau teori tertentu?, apakah memerlukan prasyarat tertentu?, apakah untuk mencapai hasil pembelajaran hanya cukup dengan satu strategi dan media saja?, dan apakah strategi dan media yang dipilih akan efektif dan efisien? (Dirjen Dikti, 2010: 88).

Dalam praktik pembelajaran daring di PT, muncul sinyalemen bahwa para dosen belum melakukan perancangan komponen-komponen pembelajaran berdasarkan acuan reflektif panduan SPM-PT dengan baik. Survei terhadap dosen FKIP yang dilakukan Lembaga Penjaminan Mutu UKSW berkaitan dengan pembelajaran daring yang selama ini dilakukan menemukan fenomena bahwa hanya $25 \%$ dosen yang menggunakan Learning Management System(LMS) untuk mendesain pembelajaran daring. Sebagian besar responden (75\%) melaksanakan pembelajaran daring menggunakan platform medsos seperti What App, Google Meet, Zoom dan Google Classroom.

Mencermati kesenjangan perkuliahan daring selama ini, diperlukan pijakan empirik melalui suatu penelitian untuk memantapkan pilihan dosen menggunakan $L M S$ dalam merancang pembelajaran daring di UKSW, khususnya di Progarm Studi PGSD-FKIP. Alternatif desain pembelajaran yang secara potensial dapat memenuhi kebutuhan pembelajaran daring tersebut adalah pembelajaran menggunakan portal Flexible Learning (Flearn). Untuk memastikan secara empirik potensi pembelajaran berbasis Flearn itulah maka dilakukan penelitian eksperimen perkuliahan daring dengan tujuan: 1) mengetahui apakah tingkat self-regulated learning mahasiswa dalam pembelajaran menggunakan Flearn lebih tinggi dibandingkan dengan pembelajaran menggunakan Google Classrom, dan 2) mengetahui apakah tingkat hasil belajar yang dimederatori oleh tingkat self-regulated learning mahasiswa lebih tinggi dibandingkan dengan pembelajaran menggunakan Google Classroom.

\section{KAJIAN PUSTAKA}

\section{Self-Regulated Learning (SRL)}

Ada berbagai istilah yang sering disepadankan dengan istilah Self-regulated Learning. Istilahistilah tersebut diantaranya adalah: Self-Motivated Learning, Resource-based Learning, Flexible Learning, Open Learning, Independent Learning, dan Distance Learning (Haris Mudjiman, 2011: 63). Perbedaan istilah ini menggambarkan perbedaan penekanan konsep yang hendak dijelaskan. Meskipun berbagai peristilahan tersebut memberikan penekanan yang berbeda-beda, tetapi semuanya memiliki hakikat yang sama, yaitu belajar yang didorong oleh keinginan untuk menguasai suatu kompetensi tertentu.

Zimmerman \& Schunk seperti dikutip oleh (Haris Mudjiman, 2011: 64) mendefinisikan SRL adalah suatu proses dimana pebelajar menggerakkan, mengubah, dan mempertahankan kegiatan belajar baik secara sendiri maupun pada lingkungan sosialnya, dalam konteks instruksional informal maupun formal. Sedangkan Haris Mudjiman (2011: 9) mendifinisikan bahwa SRL atau belajar mandiri adalah kegiatan belajar aktif, yang didorong oleh niat atau motif untuk menguasai suatu kompetensi guna mengatasi sesuatu masalah, dan dibangun dengan bekal pengetahuan atau kompetensi yang telah dimiliki. Sedangkan Hiemstra (dalam Haris Mujiman, 2011: 10) memberikan batasan bahwa SelfDirected Learning adalah perilaku siswa dalam mewujudkan kehendak atau keinginannya secara nyata dengan tidak bergantung pada orang lain, dalam hal ini adalah siswa tersebut mampu melakukan belajar sendiri, dapat menentukan cara belajar yang efektif, mampu melaksanakan tugas-tugas belajar dengan baik dan mampu untuk melakukan aktivitas belajar secara mandiri. Dari ketiga pandangan tentang 
pengertian SRL tersebut, dapat dipahami bahwa SRL hakikatnya merupakan suatu proses belajar di mana pembelajar melakukan kegiatan belajar aktif, yang didorong oleh motif untuk mengatasi sesuatu masalah, dan dibangun dengan bekal pengetahuan atau kompetensi yang telah dimiliki, serta memonitor, mengatur dan mengendalikan pikiran, dan perilakunya untuk mencapai kompetensi tertentu.

Sebagai seorang dosen, bagaimanakah kita bisa mendeteksi seberapa tinggi tingkat kemandirian belajar mahasiswa kita?. Apakah tingkat kemandirian belajar tersebut dapat digunakan untuk memprediksi hasil belajar para mahasiswa? Penelitian yang dilakukan Zimmerman (2008) menyimpulkan bahwa tingkat kemandirian belajar mahasiswa yang diukur menggunakan angket dapat digunakan untuk memprediksi hasil belajar siswa. Berbagai penelitian yang lain juga menemukan bahwa tingkat kemandirian belajar berperan dalam pencapaian kompetensi belajar mahasiswa (Stewart, 2007; Dabbagh \& Bannan-Ritland, 2005).

Berkaitan dengan instrumen yang digunakan untuk menakar tingkat kemandirian belajar siswa, Cleary, Callan \& Zimmerman (2012) menyatakan bahwa instrumen The Self-Regulate Learning Microanalytic Assessment merupakan instrumen yang ideal untuk mengukur kemandirian siswa. Namun instrumen pengukuran tingkat kemandirian belajar siswa seperti skala penilaian diri, angket online, observasi langsung maupun skala penilaian guru dan orang tua dapat juga digunakan untuk mengukur kemandirian belajar tersebut. Berdasarkan pandangan tentang instrumen untuk mengukur tingkat kemandirian belajar menurut Zimmerman (2008) dan Cleary, Callan \& Zimmerman (2012) tersebut di atas, maka instrumen rubrik penilaian diri baik secara offline maupun online dapat digunakan.

Haris Mudjiman (2011: 8) menjelaskan bahwa kemandirian belajar mahasiswa dapat diukur dari aktualisasi setiap komponen belajar mandiri. Komponen-komponen tersebut secara runtut meliputi: a) adanya motivasi atau niat belajar, b) niat untuk menguasai atau memiliki kompetensi tertentu, c) kegiatan belajar aktif untuk mencapai kompetensi dengan mengontrol perilaku diri, dan d) berbekal kompetensi yang telah dimiliki. Holt \& Singh (2012) melapokan hasil penelitian bahwa rancangan elearning yang menarik ternyata berpengaruh terhadap keputusan untuk melakukan tindakan belajar. Implikasinya bagi perancangan pembelajaran adalah bahwa para perancang pembelajaran hendaknya mengenali karakteristik pembelajaran berbasis e-learning dan menerjemahkannya dalam sebuah desain pembelajaran.

\section{Flexible Learning, e-Learning berbasis Moodle}

Flexible Learning yang kemudian sering disebut FLearn merupakan fasilitas penunjang pembelajaran dalam jaringan (online) yang dimiliki UKSW. Fasilitas ini mulai dikembangkan pada tahun 2007 dan terus digunakan sampai sekarang (tahun 2020). Flearn dikembangkan oleh Biro Teknologi dan Sistem Informasi UKSW menggunakan platform Moodle (Modular Object Oriented Dynamic Learning Environment).

Moodle merupakan salah satu software pembelajaran berbasis web (web-based instruction) dalam sistem e-learning. Oleh karena Moodle merupakan subsistem dari sistem e-learning, maka sebelum pembahasan tentang Moodle akan dijelaskan terlebih dahulu tentang e-learning. Menurut Clark \& Mayer (2008: 10), e-learning adalah pembelajaran yang disampaikan melalui computer melalui jaringan internet ataupun intranet dengan mengintegrasikan model pedagogis, strategi pembelajaran dan teknologi penyampaian materi. Smaldino, Lowther \& Russell (2005: 25), mengatakan bahwa $e$-learning adalah penyampaian konten pembelajaran atau pengalaman belajar secara elektronik mengunakan komputer dan media berbasis komputer. Berdasarkan dua pandangan tentang pengertian e-Learning tersebut, nampak bahwa sebenarnya baik Clark \& Mayer maupun Smaldino, Lowther \& Russell, keduanya menyatakan bahwa e-Learning hakikatnya merupakan sarana pembelajaran untuk menyampaikan materi menggunakan komputer dan internet dengan mempertimbangkan model pedagogis tertentu. Berkaitan dengan model pedagogis, Pujiriyanto (2012: 201) menyatakan bahwa model pedagogis adalah bangunan teoretik berlandaskan teori belajar sehingga memudahkan pelaksanaan strategi pembelajaran. Model pedagogis memiliki pandangan preskripsi pembelajaran (how to teach) dan deskripsi proses belajar (how to learn) yang dapat diterjemahkan dalam praktik pembelajaran. Deskripsi tentang e-Learning tersebut semakin memperjelas bahwa Moodle merupakan software pembelajaran berbasis web (web-based instruction)

Software Moodle dapat merubah sebuah media pembelajaran kedalam bentuk web. Software Moodle ini selalu diperbaharui sesuai dengan tuntutan dunia pendidikan muthakir. Sampai sekarang ini, software Moodle terakhir adalah versi 3.5. Moodle dikembangkan pertama kali oleh Dougiamas seperti 
dikutip oleh Limongelli, Sciarrone \& Vaste (2011: 2) merupakan software Learning Management System (LMS) yang didesain menggunakan prinsip pedagogik, untuk membantu pengajar menciptakan komunitas pembelajaran online yang efektif dan menyenangkan. Surjono (2010: 6) menjelaskan bahwa Moodle adalah perangkat lunak untuk membuat materi perkuliahan online, mengelola kegiatan pembelajaran, memfasilitasi interaksi, komunikasi, kerjasama antar dosen dan mahasiswa. Moodle mendukung berbagai aktivitas administrasi pembelajaran, peyampaian materi pembelajaran, penilaian (tugas, quiz), pelacakan/tracking \& monitoring, kolaborasi, dan komunikasi/interaksi.

Para praktisi pendidikan memilih LMS Moodle sebagai alternatif dalam mengembangkan $e$ Learning oleh karena berbagai pertimbangan, diantaranya: 1) Moodle sudah familier di kalangan institusi pendidikan di Indonesia, 2) tersedia dalam bahasa Indonesia, sehingga memu-dahkan dosen, mahasiswa dan staff admin untuk mengakses dan mengelolanya, 3) proses customization yang relatif tidak merepotkan, bahkan meskipun kita tidak memahami skil pemrograman dengan baik, 4) Template dan theme yang disediakan memadai, 5) pertimbangan praktis, terutama biayanya lebih ringan (kecuali biaya internet) karena bersifat open source, dan 6) secara empirik berdasarkan hasil penelitian terbukti sebagai $L M S$ yang handal.

Setelah menentukan pilihaan $L M S$, tidak kalah penting adalah memperhatikan bagaimana mendesain $e$-learning tersebut. Effendi dan Zhuang (2005: 94) menjelaskan bahwa beberapa hal yang harus diperhatikan dalam mendesain e-learning adalah tampilan, akses, interaksi, desain pembelajaran, dan kontrol atau navigasi. Fitur-fitur yang dikembangkan harus dapat memfasilitasi berbagai kegiatan yang dilakukan secara online. fitur-fitur tersebut antara lain manajemen bahan ajar (content management), manajemen isi perkuliahan (content/course management), manajemen pengguna (user management), tugas, quiz, komunikasi (communication tools) baik yang asynchronous maupun synchronous.

Sebagai sebuah platform pembelajaran daring, Moodle memiliki kekuatan dan kelemahan. Dietinger (2003: 23) berpendapat bahwa pembelajaran berbasis Moodle e-learning memiliki beberapa kelebihan yaitu terjadinya kemandirian dalam proses pembelajaran, tidak tergantung pada tempat pembelajaran sehingga pembelajaran dapat dilaksakan dimana saja dan di tempat yang berbeda-beda, pendistribusian informasi baru sangat cepat karena didistribusikan secara digital, peserta didik dapat belajar sesuai dengan kecepatanya masing-masing, sesuai dengan gaya belajarnya sehingga dapat mencapai kompetensi yang diharapkan, serta pembelajaran berbasis multimedia dapat memotivasi peserta didik dalam belajar. Kelemahan e-learning meliputi tidak adanya kontak fisik secara langsung antara dosen dan mahasiswa serta sesama mahasiswa, belajar dari komputer susah dipahami, dapat mengganggu kesehatan mata, hanya sedikit pembelajar online yang menyelesaikan pendidikan secara tuntas, penginstalan sistem pembelajaran sangat rumit. Jika dibandingkan dengan kelemahan Moodle, maka kekuatan Moodle nampaknya lebih menguntungkan jika dipilih sebagai alternatif LMS untuk pembelajarn daring. Mencermati kekuatan Moodle e-learning tersebut di atas, ada dua hal penting yang perlu diperhatikan dalam mendesain pembelajaran berbasis e-learning, yaitu tumbuhnya kemandirian dalam proses pembelajaran dan e-learning memungkinkan mahasiswa belajar sesuai dengan gaya belajarnya sehingga dapat mencapai kompetensi yang diharapkan.

Pada tataran implementasinya, berbagai penelitian tentang Moodle mengisyaratkan bahwa aplikasi ini sangat baik digunakan untuk pembelajaran daring. Ramayah (2010) melakukan penelitian quantitative survey tentang the role of voluntariness in distance education students' usage of a course website, menemukan bahwa pembekajaran daring menggunakan e-learning berbasis Moodle memberikan kemudahan penggunaan dalam sistem perkuliahan dan berdampak signifikan terhadap kemandirian dan hasil belajar $(\beta=0.488, \mathrm{p}<0.01)$. Burhanuddin (2011) melakukan penelitian tentang pengembangan e-learning dengan moodle sebagai alternatif media pembelajaran berbasis internet menemukan hasil bahwa e-learning sekolah dengan berbasis Moodle yang telah dikembangkan berjalan dengan baik. Sedangkan Girard \& Pinar (2011) melaporkan hasil penelitian tentang penggunaan LMS Moodle menyatakan bahwa nilai rata-rata hasil belajar mahasiswa menunjukkan angka lebih tinggi secara signifikan dengan tingkat kepercayaan $99 \%(\mathrm{p}<0,01)$ dibandingkan pembelajaran menggunakan media pembelajaran yang lain.

\section{Google Classroom (GC)}

$G C$, merupakan layanan web gratis, yang dikembangkan oleh Google untuk pembelajaran, yang bertujuan untuk mendesain, mendistribusikan, dan menilai tugas dengan cara online. Google Classroom menggabungkan Google Drive untuk pembuatan dan pengiriman penugasan, Google Docs, Sheets, dan 
Slides untuk penulisan, Gmail untuk komunikasi, dan Google Calendar untuk penjadwalan. Mahasiswa dapat diundang untuk bergabung dengan kelas melalui kode pribadi, atau secara otomatis diimpor dari domain lembaga. Setiap kelas berada pada folder terpisah di Drive masing-masing pengguna, di mana mahasiswa dapat mengirimkan pekerjaan untuk dinilai oleh dosen. GC dapat juga diakses menggunakan aplikasi seluler, baik untuk perangkat iOS maupun Android. Melalui fitur ini pengguna dapat mengambil foto dan melampirkan penugasan, berbagi file dari aplikasi lain, dan mengakses informasi secara offline. Dosen dapat memantau kemajuan untuk setiap mahasiswa, dan setelah dinilai, dosen dapat kembali bekerja bersama dengan komentar (https://id.wikipedia.org/wiki/Google_Kelas).

Informasi tentang apa itu GC dikemukakan juga oleh Martínez-Monés, A., Reffay, C., Torío, J. H., \& Cristóbal, J. A. M. (2017: 2) mendeskripsikan GC berikut:

"Google Classroom (GC) is a collaborative tool for teachers and students thatbuilds on existing Google technologies, mainly Google Docs, Google Drive, and Gmail. A teacher working with GC can setup classes to which students can join using a code provided by the platform. Within a course, teachers can: create and distribute assignments and attach different types of documents to them;monitor the state of the students' submissions; and providefeedback to the students once the assignment is turned in. Teachers can grade the assignments and manage the grades using Google Spreadsheets"

Kutipan tentang pengertian $G C$ dari dua sumber di atas memberikan gambaran bahwa $G C$ merupakan software tidak berbayar berbasis Word Wide Web $(W W W)$ yang dapat digunakan untuk mendesain pembelajaran daring. Dapat diakses menggunakan perangkat komputer mapun perangkat selular berbasis iOS maupun Android. Sebagai platform pembelajaran daring, GC memiliki berbagai fitur pembelajaran berikut: 1) Penugasan, yaitu fitur yang memungkinkan kolaborasi antara dosen dan mahasiswa atau mahasiswa dengan mahasiswa yang lain. Berbagai dokumen yang berada di Google Drive, kemudian dikirim untuk dinilai. Dosen dapat memilih file yang kemudian dapat diperlakukan sebagai template sehingga setiap siswa dapat mengedit salinan mereka sendiri dan kemudian kembali untuk dinilai. Siswa juga dapat memilih melampirkan dokumen tambahan dari Drive mereka ke fitur tugas; 2) Penilaian, yaitu fitur $G C$ mendukung berbagai sistem penilaian yang berbeda. Dosen memiliki opsi untuk melampirkan file ke tugas yang dapat dilihat mahasiswa, diedit, atau mendapatkan salinan individu. Mahasiswa dapat membuat file dan kemudian melampirkannya ke tugas jika salinan file tidak dibuat oleh Dosen. Dosen juga memiliki opsi untuk memantau kemajuan setiap siswa pada tugas di mana mereka dapat membuat komentar dan mengedit. Tugas yang diubah dapat dinilai oleh guru dan dikembalikan dengan komentar untuk memungkinkan siswa merevisi tugas. Setelah dinilai, tugas hanya dapat diedit oleh dosen kecuali dosen mengembalikan tugas mahasiswa tersebut; 3) Komunikasi, yaitu fitur yang berisi fasilitas pengumuman dapat diposting oleh dosen ke pengumuman kelas yang dapat dikomentari oleh mahasiswa, sehingga memungkinkan komunikasi dua arah. Mahasiswa juga dapat memposting ke pengumuman kelas tetapi tidak leluasa. Berbagai jenis media dari produk Google seperti video YouTube dan file Google Drive dapat dilampirkan ke pengumuman. Gmail juga menyediakan opsi email bagi dosen untuk mengirim email ke satu atau lebih mahasiswa di antarmuka $G C$. Pengumuman ini dapat diakses di web atau melalui aplikasi seluler berbasis Android dan iOS; 4) Laporan Orisinalitas tulisan, yaitu . fitur yang berisi laporan tulisan yang dibuat mahasiswa memiliki kemiripan atau similaritas dengan tulisan dari sumber lain; 5) Arsip perkuliahan. Ruang Kelas memungkinkan instruktur untuk mengarsipkan kursus pada akhir semester atau tahun. Ketika sebuah kursus diarsipkan, itu dihapus dari beranda dan ditempatkan di area arsip perkuliahan; 6) Aplikasi seluler, yaitu fitur GC, yang dapat disinkronisasi dengan perangkat berbasis iOS dan Android. Aplikasi memungkinkan pengguna mengambil foto dan melampirkannya ke tugas mereka, berbagi file dari aplikasi lain, dan mendukung akses offline; 7) Privasi, yaitu fitur $G C$, sebagai bagian dari $G$ Suite for Education, tidak menampilkan iklan apa pun dalam antarmuka untuk mahasiswa, dosen, dan data pengguna (https://id.wikipedia.org/wiki/Google_Kelas\#Fitur).

Berbagai penelitian tentang implementasi $G C$ dalam pembelajaran daring dilaporkan oleh beberapa peneliti berikut: Asnawi, N. (2018: 21) melaporkan hasil penelitian tentang Usability Aplikasi Google Classroom sebagai E-learning menggunakan USE Questionnaire bahwa aplikasi GC yang digunakan oleh dosen di program studi Sistem Informasi UNIPMA sebagai e-learning secara keseluruhan memiliki nilai yang belum begitu baik. Dilihat dari skor faktor usefulness (kegunaan) diperoleh angka sebesar 3,13 yang menunjukkan bahwa aplikasi $G C$ telah memiliki kegunaan yang 
baik, artinya bahwa aplikasi ini berguna jika digunakan sebagai $e$-learning. Dilihat dari faktor ease of use (kemudahan penggunaan) diperoleh skor sebesar 2,93 yang menunjukkan bahwa aplikasi Google Classroom telah memiliki kemudahan dalam penggunaan yang kurang baik, artinya bahwa aplikasi ini masih ada kesulitan dalam proses penggunaannya; Dilihat dari faktor ease of learning (kemudahan belajar) diperoleh skor sebesar 2,75 yang menunjukkan bahwa aplikasi Google Classroom telah memiliki kemudahan dalam belajar yang kurang baik, artinya bahwa aplikasi ini masih ada kesulitan dalam proses belajar menggunakannya; Dilihat dari faktor satisfaction (kepuasan) diperoleh skor sebesar 2,8 yang menunjukkan bahwa aplikasi Google Calssroom telah memiliki kepuasan yang kurang baik, artinya bahwa aplikasi ini masih belum memuaskan dalam penggunaanya sebagai elearning. Hal ini juga dipengaruhi oleh faktor ease of use dan ease of learning yang kurang baik yang menyebabkan nilai kepuasan menjadi kurang baik.

Peneliti lain, Iftakhar, S. (2016: 17), seorang dosen dari Department of English, Daffodil International University (DIU), Dhaka, Bangladesh, meneliti tentang Google Classroom: What Works And How?, melaporkan bahwa fitur-fitur yang disediakan dalam Google Classroom sangat membantu para dosen dan mahasiswa DIU dalam melaksanakan pembelajaran online, dan dapat menumbuhkan kemandirian belajar para mahasiswa. Sedangkan Azhar, K. A., \& Iqbal, N. (2018: 63), peneliti dari Barrett Hodgson University, Pakistan meneliti tentang Effectiveness of Google classroom: Teachers' perceptions, melaporkan bahwa pembelajaran daring menggunakan Google Classroom tidak berdampak signifikan terhadap pengajaran kelas secara keseluruhan. Berkaitan dengan tampilan antarmuka, fitur ini dianggap kurang ramah oleh dosen dan mahasiswa.

\section{METODE}

Jenis penelitian yang digunakan untuk mengetahui pencapaan tujuan ini adalah jenis eksperimen menggunakan model The Matching-only Pretest-posttest Control Group design dan Factorial design. Partisipan dalam eksperimen ini melibatkan peserta matakuliah Penelitian dan Inovasi Pembelajaran (PIP) sejumlah 74 orang, dengan rincian 36 mahasiswa dan 1 orang dosen pengampu mata kuliah sebagai kelompok eksperimen 1 serta 36 mahasiswa dan 1 orang dosen sebagai kelompok kontrol (eksperimen 2). Pada kelompok eksperimen 1 dikenakan tindakan pembelajaran daring menggunakan Flearn, sedangkan pada kelompok eksperimen 2 dilakukan pembelajaran daring dengan Google Classroom. Instrumen penelitian menggunakan soal tes untuk mengukur variabel hasil belajar mahasiswa dan rubrik skala self-regulated learning untuk mengukur tingkat self-regulated learning mahasiswa. Teknik analisis data menggunakan teknik Independent Sample t-Test dan ANCOVA. Sebelum instrumen digunakan, terlebih dahulu dilakukan uji reliabilitas dan validitas kedua instrumen. Dilakukan juga uji normalitas persebaran data dan uji homogenitas variansi data hasil uji coba. Hasilnya menunjukkan bahwa instrumen dinyatakan reliabel dan valid. Persebaran data diketahui normal dan variaansinya homogen. Teknik uji hipotesis menggunakan Independent Sample t-Test untuk menguji Hipotesis1, dimana $\mathrm{H}_{0}$ : "Pembelajaran daring menggunakan Flearn tidak lebih tinggi secara signifikan dalam menumbuhkan SRL mahasiswa daripada model pembelajaran menggunakan Google Classroom". Teknik uji ANCOVA untuk menguji Hipotesis 2 dan 3. Hipotesis 2, $\mathrm{H}_{0}$ : "Pembelajaran menggunakan Flearn memberikan dampak tidak lebih tinggi secara signifikan terhadap hasil belajar mahasiswa yang dimoderatori oleh SLR mahasiswa daripada model pembelajaran menggunakan Google Classroom".

\section{HASIL DAN PEMBAHASAN Hasil Penelitian}

Penelitian eksperimen hakikatnya adalah menguji keefektifan atau keampuhan suatu tindakan pembelajaran dalam rangka mencapai tujuan. Keefektifan atau keampuhan suatu tindakan pembelajaran tersebut benar-benar nyata berbeda dengan tindakan pembelajaran yang lain. Dalam konteks penelitian eksperimen ini, peneliti menguji keefektifan tindakan pembelajaran menggunakan Flearn dalam menumbuhkan SRL yang pada gilirannya akan meningkatan hasil belajar mahasiswa dibandingkan dengan pembelajaran menggunakan Google Classroom.Data hasil penelitian berkaitan dengan keefektifan tindakan pembelajaran menggunakan Flearn dalam menumbuhkan SRL mahasiswa dirangkum dalam Tabel 1. 
Tabel 1. Tingkat SRL Mahasiswa

\begin{tabular}{cccc}
\hline \multirow{2}{*}{ Pengukuran } & \multicolumn{2}{c}{ Rerata SRL } & \multirow{2}{*}{ Selisih skor } \\
\cline { 2 - 3 } & \multicolumn{2}{c}{ Kelompok } & \\
\cline { 2 - 3 } & Eksperimen1 & Eksperimen2 & \\
\hline Awal daring & 69,85 & 68,50 & 1,35 \\
Akhir daring & 74,86 & 70,40 & 4,46 \\
\hline
\end{tabular}

Pada pengukuran awal pembelajaran daring pada kelompok eksperimen 1 rerata skor SRL hanya 69,85. Pada pengukuran akhir, rata-rata SRL mahasiswa naik menjadi 74,86. Kenaikan rata-rata SRL mahasiswa juga nampak pada kelompok eksperimen 2 sebagai kelompok kontrol. Pada kelompok kontrol, rerata pengukuran awal daring mencapai 68,50, sedangkan pengukuran akhir daring menjadi 70,40 .

Data berkaitan dengan keefektifan tindakan pembelajaran menggunakan Flearn dalam meningkatkan hasil belajar mahasiswa dirangkum dalam Tabel 2 .

Tabel 2. Tingkat hasil Belajar Mahasiswa

\begin{tabular}{|c|c|c|c|}
\hline \multirow{3}{*}{ Tes } & Rerata Skor $(M e$ & Hasil Belajar & \multirow{3}{*}{$\begin{array}{c}\text { Selisih } \\
\text { skor }\end{array}$} \\
\hline & \multicolumn{2}{|c|}{ Kelompok } & \\
\hline & Eksperimen1 & Eksperimen2 & \\
\hline Pretes & 57,39 & 52,44 & 4,95 \\
\hline Postes & 73.92 & 64,14 & 8.78 \\
\hline
\end{tabular}

Pada pretes kelompok eksperimen1 rerata skor hasil belajar hanya 57,39. Pada postes, rata-rata hasil belajaran mahasiswa naik menjadi 73,92. Kenaikan rata-rata hasil belajar mahasiswa juga nampak pada kelompok eksperimen 2. Pada kelompok eksperimen 2, rerata pretes mencapai 52,44, sedangkan postes menjadi 64,14. Jika data tingkat SRL dan hasil belajar ini dikomparasikan berdasarkan tingkat SLR tinggi dan rendah, maka datanya menjadi seperti pada Tabel 3. Data rerata hasil pretes berdasarkan kategori tingkat SRL tinggi, secara tersirat nampak bahwa gain score hasil belajar mahasiswa pada kelompok eksperimen 1 mencapai 3,55. Gain score pada kelompok eksperimen1 yang memiliki SRL rendah mencapai 6,37. Data rerata hasil postes berdasarkan kategori tingkat SRL tinggi pada kelompok eksperimen 2 mencapai 10. Gain score pada kelompok eksperimen 2 yang memiliki SRL rendah mencapai 9,56.

Tabel 3. Komparasi Tingkat SRL dan hasil belajar Mahasiswa

\begin{tabular}{cccccc}
\hline \multirow{2}{*}{$\begin{array}{c}\text { Tingkat } \\
\text { SRL }\end{array}$} & \multicolumn{4}{c}{$\begin{array}{c}\text { Rerata, SD } \\
\text { dan Varian }\end{array}$} & \multicolumn{2}{c}{$\begin{array}{c}\text { Flearn } \\
\text { (eksperimen 1) }\end{array}$} & \multicolumn{2}{c}{$\begin{array}{c}\text { Hoogle Classroom } \\
\text { (eksperimen 2) }\end{array}$} \\
\cline { 2 - 6 } & $\begin{array}{c}\text { Pretes } \\
\text { Tinggi }\end{array}$ & Postes & Pretes & Postes \\
\hline \multirow{2}{*}{ Rerata } & 58 & 76,34 & 54,45 & 66,34 \\
\cline { 2 - 6 } & SD & 8,067 & 12,023 & 9,639 & 6,872 \\
\cline { 2 - 6 } & Varian & 66,593 & 146,867 & 94,75 & 48,514 \\
\hline \multirow{3}{*}{ Rendah } & Rerata & 54,6 & 69,29 & 48,23 & 59,73 \\
\cline { 2 - 6 } & SD & 9,601 & 13,913 & 9,805 & 10,877 \\
\cline { 2 - 6 } & Varian & 94,018 & 196,269 & 98,018 & 120,4 \\
\hline
\end{tabular}

Berkaitan dengan uji statistik, data tingkat SRL ini kemudian diuji menggunakan uji $\mathrm{T}$ dan ANCOVA. Ringkasan uji T seperti tertera dalam Tabel 4 memberikan informasi besarnya nilai $\mathrm{T}$ dan sigifikansinya. Pada kolom Equal variances assumed nampak T hitung sebesar 3,970 dengan taraf signifikansi hitung 0,000. Ringkasan uji ANCOVA tertera dalam Tabel 5. 
Keefektifan Flexible Learning dalam Menumbuhkan Self-Regulated Learning dan Hasil Belajar Mahasiswa PGSD (Mawardi)

Tabel 4. Hasil Uji T Tingkat SRL Mahasiswa

Independent Samples Test

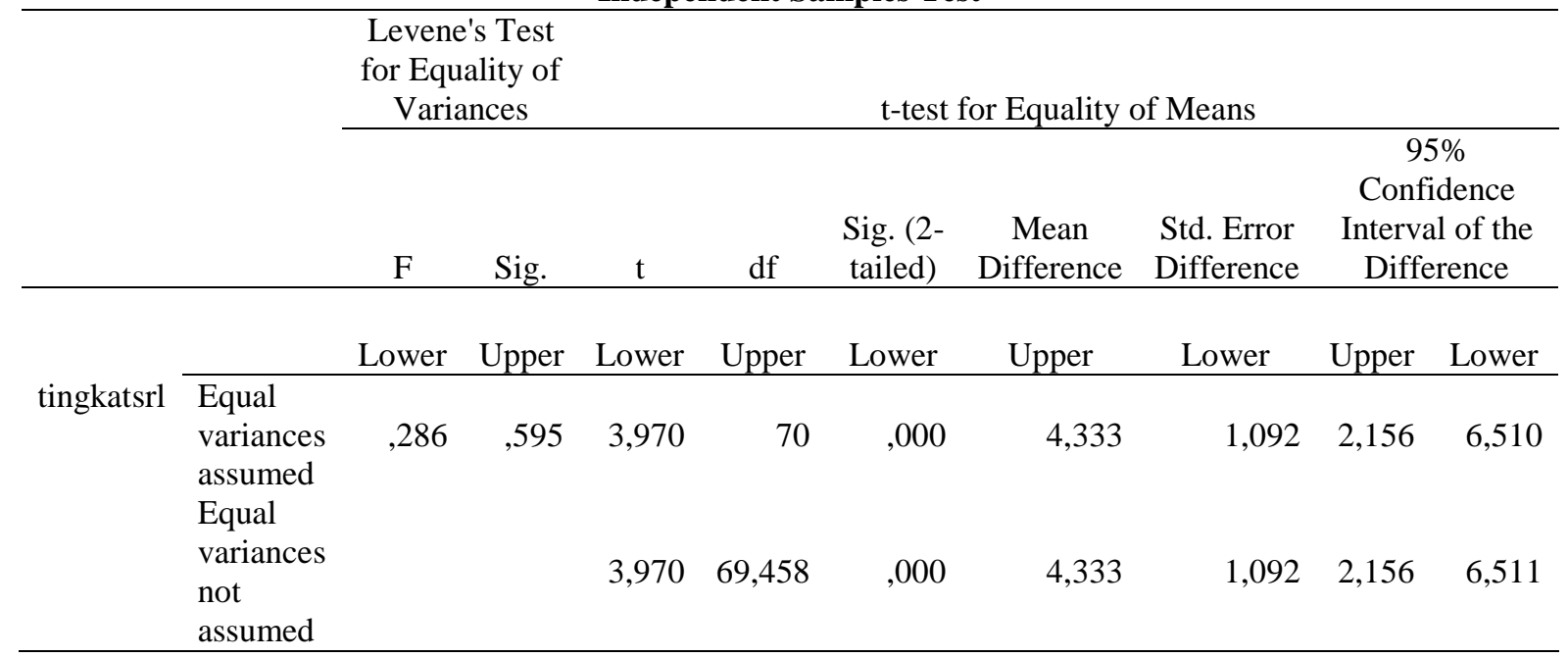

Ringkasan uji ANCOVA seperti tertera dalam Tabel 4 memberikan informasi besarnya nilai $\mathrm{F}$ dan sigifikansinya serta berbagai variansinya. Pada sumber varian corrected model, nampak bahwa $\mathrm{F}$ hitung sebesar 6,455 dengan taraf signifikansi hitung 0,001. Pada varian intercept nampak bahwa $F$ hitung sebesar 2582,063 dengan taraf signifikansi hitung 0,000. Pada kovarian tingkat SRL, diperoleh data $\mathrm{F}$ hitung 5,995 dengan taraf signifikansi 0,017. Pada varian kelompok, diperoleh nilai $\mathrm{F}$ hitung sebesar 13,336dengan signifikansi hitung 0,001. Varian terakhir, yaitu pada varian interkasi kelompok dengan tingkat SRL, diperoleh data F hitung 0,035dengan taraf signifikansi hitung 0,852.

Pembahasan

Pada uraian bagian metode, telah dikemukakan bahwa ada dua hipotesis yang akan diuji untuk mengetahui efektivitas model ini. Hipotesis 1 , dimana $\mathrm{H}_{0}$ : "Pembelajaran daring menggunakan Flearn tidak lebih tinggi secara signifikan dalam menumbuhkan $S R L$ mahasiswa daripada model pembelajaran menggunakan Google Classroom" ternyata ditolak dan diterima Ha. Artinya bahwa pembelajaran menggunakan Flearn memberikan dampak lebih tinggi secara signifikan terhadap tumbuhnya SLR mahasiswa daripada model pembelajaran menggunakan $G C$. Simpulan ini didasarkan pada data ratarata tingkat belajar mandiri kelompok eksperimen 1 mencapai 73,92, dan kelompok eksperimen 2 sebagai kelompok kontrol mencapai 64,14 $(73,92>64,14)$. Signifikansi perlakuan didasarkan pada data temuan T hitung sebesar 3,970; $\mathrm{p}=0,000(\mathrm{p}=0,000<\alpha=0,050)$.

Keampuhan Flearn dalam menumbuhkan $S R L$ belajar berasal dari faktor desain pembelajaran yang dapat menumbuhkan motivasi untuk belajar sebagai komponen dasar dalam belajar mandiri. Motivasi untuk belajar ini tumbuh karena belajar melalui portal belajar online terasa menyenangkan. Motivasi juga tumbuh karena adanya bimbingan dan dorongn dari fasilitator untuk menggunakan fitur chatting, message dan link ke URL tertentu untuk mencari sumber bahan maupun informasi berkaitan dengan materi pembelajaran. Fenomena empirik dalam pembelajaran online ini didasarkan pada pandangan Mudjiman (2011: 4), bahwa penumbuhan kemampuan belajar mandiri dalam konteks pendidikan, menyangkut segi penumbuhan pada diri siswa niat untuk belajar, dan pengembangan kemampuan teknis belajar. Pendapat ini senada dengan simpulan penelitian Song \& Hill (2007), bahwa efektivitas dalam belajar mandiri tergantung pada seberapa tingkat pengarahan diri sendiri (atribut pribadi). 
Scholaria: Jurnal Pendidikan dan Kebudayaan, Vol. 10 No. 3, September 2020: 251-262

Tabel 5. Hasil Uji ANCOVA Tingkat SRL dan Hasil Belajar Mahasiswa

\section{Tests of Between-Subjects Effects}

\begin{tabular}{|c|c|c|c|c|c|}
\hline Source & $\begin{array}{l}\text { Type III Sum } \\
\text { of Squares }\end{array}$ & df & Mean Square & $\mathrm{F}$ & Sig. \\
\hline Corrected Model & 2498,944(a) & 3 & 832,981 & 6,455 & ,001 \\
\hline Intercept & 333200,056 & 1 & 333200,056 & 2582,063 & ,000 \\
\hline kelompok & 1720,889 & 1 & 1720,889 & 13,336 & 001 \\
\hline tingkatslr & 773,556 & 1 & 773,556 & 5,995 & ,017 \\
\hline kelompok * tingkatslr & 4,500 & 1 & 4,500 & 035 & 852 \\
\hline Error & 8775,000 & 68 & 129,044 & & \\
\hline Total & 344474,000 & 72 & & & \\
\hline Corrected Total & 11273,944 & 71 & & & \\
\hline
\end{tabular}

Tumbuhnya SLR ini didorong oleh kesadaran bahwa pengalaman belajar (terutama dalam pemecahan masalah) dengan pengaturan diri sendiri ini akan menjadi bekal pembelajaran sepanjang hayat. Pembelajaran sepanjang hayat diperlukan oleh karena setiap orang pasti mengalami masalah dalam perjalanan hidupnya. Pengalaman pemecahan masalah yang telah dialami dan dibiasakan dalam pendidikan formal di perguruan tinggi akan menjadi bekal dalam memecahkan masalah apapun dalam kehidupan seseorang. Pemecahan masalah dalam pendidikan formal maupun dalam kehidupan sesehari memerlukan kegiatan belajar yang dilandasi oleh dorongan dari dalam diri sendiri untuk belajar dan pengalaman ketrampilan belajar yang telah dimiliki (Mudjiman, 2011: 5). Temuan bahwa pembelajaran daring menggunakan Flearn menumbuhkan SRL seseorang sejalan dengan temuan penelitian Usta (2011). Penelitian ini menemukan bahwa ada hubungan positif dan signifikan $(\mathrm{r}=0,207)$ antara sikap terhadap pembelajaran daring dengan keterampilan belajar yang diatur oleh dirinya sendiri.

Hipotesis 2, $\mathrm{H}_{0}$ : "Pembelajaran menggunakan Flearn memberikan dampak tidak lebih tinggi secara signifikan terhadap hasil belajar mahasiswa yang dimoderatori oleh SLR mahasiswa daripada model pembelajaran menggunakan Google Classroom", ternyata ditolak dan diterima $\mathrm{H}_{\mathrm{a}}$. Artinya bahwa pembelajaran menggunakan Flearn memberikan dampak tidak lebih tinggi secara signifikan terhadap hasil belajar mahasiswa yang dimoderatori oleh $S L R$ mahasiswa daripada model pembelajaran menggunakan GC. Signifikansi perlakukan terlihat dari F hitung sebesar 13,336; $p=0,001$ ( $p=0,001$ $<\alpha=0,050)$ dan perbandingan rata-rata skor yang telah disesuaikan $\left(\mu_{\text {-adj }}\right) . \mu_{\text {-adj }}$ hasil belajar mahasiswa yang memiliki SRL tinggi pada kelompok eksperimen 1 menggunakan Flearn mencapai 76,34, sedangkan yang memiliki SRL rendah mencapai 69,29. Pada kelompok pembelajaran yang menggunakan $G C$ sebagai kelompok eksperimen $2, \mu_{\text {-adj }}$ skor hasil belajar mahasiswa yang memiliki

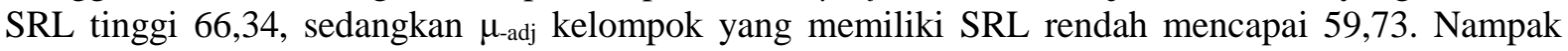
bahwa $\mu_{\text {-adj }}$ kelompok yang menggunakan Flearn, baik yang memiliki SRL tinggi maupun rendah semuanya lebih tinggi dari kelompok mahasiswa yang menggunakan $G C$.

Keefektifan Flearn memberikan dampak lebih tinggi terhadap hasil belajar mahasiswa merupakan sinergi dan integrasi desain pembelajaran daring mata kuliah PIP - teknologi penyampaian materi pembelajaran (delivery technology) yang terdapat pada Flearn. Model desain mata kuliah PIP menggunakan sistem daring berbasil Moodle didesain menggunakan model desain pembelajaran sistemik yang dikembangkan oleh Dick, Carey \& Carey (2009). Menurut Joyoatmojo (2011: 66), mendesain pembelajaran dengan model sistemik memiliki keunggulan dalam mengefektifkan pembelajaran karena tiga alasan. Pertama, kejelasan tujuan pembelajaran sebagai acuan akan memperjelas tahapan langkah pembelajaran dan cara mengimplementasikannya. Kedua, adanya keterkaitan yang sangat erat antar komponen sistem terutama tujuan dan strategi pembelajaran akan mempermudah mewujudkan tujuan pembelajaran. Ketiga, proses pembelajarn dengan pendekatan sistem merupakan proses empiris dan dapat direplikasi. Sedangkan kontribusi komponen strategi belajar mandiri dalam sinerginya menjadikan model eksperimen ini efektif dalam meningkatkan kompetensi hasil belajar mahasiswa oleh karena langkah-langkah belajar mandiri efektif membekali mahasiswa 
untuk mencapai kompetensi belajarnya. Temuan bahwa Flearn lebih efektif dibandingkan $G C$ ini sejalan dengan temuan penelitian Stewart (2007) yang menyatakan bahwa ada korelasi positif linier antara tingkat $S R L$ dengan hasil belajar para mahasiswa teknik sipil Griffith University - Gold Coast, Australia $(\mathrm{r}=0,70)$. Artinya bahwa para mahasiswa yang memiliki tingkat $S R L$ yang tinggi akan memilki hasil belajar yang tinggi pula, demikian sebaliknya.

Keefektifan Flearn dilihat dari pandangan Dabbagh \& Bannan-Ritland (2005: 207), bahwa mahasiswa mengeksplorasi materi dari berbagai sumber melalui internet, baik yang telah disiapkan oleh dosen melalui tautan ke alamat portal terrtentu maupun melakukan pencarian sendiri dan melakukan pemecahan masalah melalui diskusi online ternyata lebih efektif. Strategi dialogis memungkinkan mahasiswa melakukan pembelajaran kolaboratif, artikulatif dan reflektif. Sedangkan strategi pendukung memungkinkan mahasiswa belajar erdasarkan teknik scaffolding. Kontribusi teknologi penyampaian materi pembelajaran menggunakan Flearn terhadap efektifnya desain pembelajaran daring ini dilihat dari potensi yang dimilki Flearn itu sendiri. Secara potensial, Flearn sebagai platform pembelajaran daring berbasis Moodle memenuhi kriteria pemilihan dari Koswara N (2008: 2), yang menyatakan pemilihan harus didasarkan pada kebutuhan mahasiswa, strategi pembelajaran dan keterbatasan pelaksanaannya.

Temuan menarik pada varian tingkat $S R L$ tinggi dan rendah adalah tidak ditemukannya perbedaan signifikan kompetensi hasil belajar mahasiswa yang memiliki tingkat $S R L$ tinggi dan rendah $(\mathrm{F}=5,995, \mathrm{p}=0,17>\alpha=0,050)$. Demikian juga pada varian interkasi model pembelajaran dengan tingkat $S R L$ tinggi-rendah tidak signifikan ( $\mathrm{F}$ hitung $\mathrm{F}=0,035, \mathrm{p}=0,852>\alpha=0,050$ ). Artinya bahwa tidak ada perbedaan kompetensi hasil belajar antara mahasiswa yang memiliki tingkat $S R L$ tinggi maupun rendah. Dengan kata lain dapat dinyatakan bahwa baik mahasiswa yang memiliki $S R L$ tinggi dan rendah memiliki peluang mencapai kompetensi belajar yang lebih baik dengan perlakuan pembelajaran dengan menggunakan Flearn. Temuan penelitian ini sejalan dengan temuan penelitian eksperimen yang dilakukan Hui \& Umar (2011), bahwa tidak terdapat perbedaan signifikan kemampuan mengingat mahasiswa yang memiliki tingkat $S R L$ tinggi-rendah dalam mengikuti pembelajaran.

\section{SIMPULAN}

1. Tingkat self-regulated learning mahasiswa dalam pembelajaran menggunakan Flearn lebih tinggi secara signifikan dibandingkan dengan pembelajaran menggunakan Google Classroom, Simpulan ini didasarkan pada data rata-rata tingkat belajar mandiri kelompok eksperimen 1 mencapai 73,92, dan kelompok eksperimen 2 sebagai kelompok kontrol mencapai 64,14 (73,92 > 64,14). Signifikansi perlakuan didasarkan pada data temuan T hitung sebesar 3,970; $p=0,000(p=0,000$ $<\alpha=0,050)$.

2. Tingkat hasil belajar mahasiswa dalam pembelajaran menggunakan Flearn yang dimoderatori oleh tingkat SRL mahasiswa lebih tinggi secara signifikan dibandingkan dengan pembelajaran menggunakan $G C$. Simpulan ini didasarkan pada temuan $\mu_{\text {-adj }}$ hasil belajar mahasiswa yang memiliki SRL tinggi pada kelompok eksperimen 1 menggunakan Flearn mencapai 76,34, sedangkan yang memiliki $S R L$ rendah mencapai 69,29. Pada kelompok pembelajaran yang menggunakan $G C$ sebagai kelompok eksperimen 2, $\mu_{\text {-adj }}$ skor hasil belajar mahasiswa yang memiliki $S R L$ tinggi 66,34, sedangkan $\mu_{\text {-adj }}$ kelompok yang memiliki $S R L$ rendah mencapai 59,73. Nampak bahwa $\mu_{\text {-adj }}$ kelompok yang menggunakan Flearn, baik yang memiliki SRL tinggi maupun rendah semuanya lebih tinggi dari kelompok mahasiswa yang menggunakan $G C$. Signifikansi perlakukan terlihat dari uji ANCOVA, dimana F hitung sebesar 13,336; $\mathrm{p}=0,001(\mathrm{p}=0,001<\alpha=$ $0,050)$.

\section{DAFTAR PUSTAKA}

Asnawi, N. (2018). Pengukuran Usability Aplikasi Google Classroom Sebagai E-learning Menggunakan USE Questionnaire (Studi Kasus: Prodi Sistem Informasi UNIPMA). RESEARCH: Computer, Information System \& Technology Management, 1(1), 17-21.

Azhar, K. A., \& Iqbal, N. (2018). Effectiveness of Google classroom: Teachers' perceptions. Prizren Social Science Journal, 2(2), 52-66. 
Clark, R. C. \& Mayer, R., E. (2008). E-Learning and the science of instruction (second edition). San Francisco: Pfeiffer.

Cleary,T., J., Callan, G., L., \& Zimmerman, B.J. (2012). Assessing Self-Regulation as a Cyclical, Context-Specific Phenomenon: Overview and Analysis of SRL Microanalytic Protocols Journal of Education Research International, 2012 (2012), 108 - 127.

Dabbagh, N. \& Bannan-Ritland, B. (2005). Online learning, concepts, strategies, and application.Upper Saddle River, N.J: Pearson Education, Inc.

Dirjen Dikti. (2010). Sistem Penjaminan Mutu Perguruan Tinggi (SPM-PT).Jakarta: Kemendiknas.

Dick, W; Carey, L \& Carey, J .O. (2009). The systematic design of instruction,(seventh edition).Upper Saddle River, N.J : Pearson Education, Inc.

Dietinger,Thomas. (2003). Aspects of E-Learning Environments. Dissertation for the Award of the Academic Degree Doctor of Technical Sciencesat Graz University of Technology. Austria: Institute for Information Processing and Computer Supported New Media (IICM).

Effendi, E. \& Zhuang, H. (2005). E-learning, konsep dan aplikasi. Yogyakarta: Andi Offset.

Girard, Tulay \& Pinar, Musa. (2011). A Usability Study Of Interactive Web-Based Modules. TOJET: The Turkish Online Journal of Educational Technology, 10 (3).

Haris Mudjiman. (2011). Belajar Mandiri: Pembekalan dan Penerapan. Surakarta: Universitas Sebelas Maret Press.

Holt, L., \& Singh, V.(2012). Self-Directed Learning and Open Source Software Forum Participants: Characteristics and Relationships. International Journal of Self-Directed Learning, 9(1),11-23. Retrieved from http:// sdlglobal.com/ journals.php.

Hui, T. H., \& Umar, I., N. (2011). Does A Combination Of Metaphor And Pairing Activity Help Programming Performance Of Students With Different Selfregulated Learning Level?. TOJET: The Turkish online journal of educational technology, 10 (4), 121-129.

Iftakhar, S. (2016). Google classroom: what works and how. Journal of Education and Social Sciences, $3(1), 12-18$.

Joyoatmojo, S. (2011). Pembelajaran efektif, pembelajaran yang membelajarkan. Surakarta: Universitas Sebelas Maret Press.

Koswara, E., N. (2008). Pendidikan tunggi berbasis e-learning. Retrieved from http://www.drn.go.id/index.php?option=isi\&task=view\&id=169\&Itemid=2 (3 November 2012)

Limongelli, C. F. Sciarrone, G. Vaste. (2011). Personalized e-learning in Moodle: the Moodle_Learning Management System, Journal of e-Learning and Knowledge Society, 7 (1), 49-58.

Martínez-Monés, A., Reffay, C., Torío, J. H., \& Cristóbal, J. A. M. (2017: ). Learning Analytics with Google Classroom: Exploring the Possibilities. In Proceedings of the 5th International Conference on Technological Ecosystems for Enhancing Multiculturality(p. 47:1-47:6). New York, NY, USA: ACM. https://doi.org/10.1145/3144826.3145397

Mawardi. (2011). Alumni's competences and user satisfaction of Primary Teacher Training Departmen, Faculty of Teacher Training and Education-Satya Wacana Christian University. SCHOLARIA . 1 (2) 60-87.

Mawardi, Haris Mudjiman, Sri Anitah dan Asrowi. (2014). The Model of Instructional Design Based on Self-Regulated Learning Using Moodle. Journal of Education and Practice. 5 (22), 131 140.

Pujiriyanto. (2012). Teknologi untuk pengembangan media dan pembelajaran. Yogyakarta:UNY Press.

Ramayah, T. (2010). The Role Of Voluntariness In Distance Education Students' Usage Of A Course Website. TOJET: The Turkish online journal of educational technology, 9 (3). 
Keefektifan Flexible Learning dalam Menumbuhkan Self-Regulated Learning dan Hasil Belajar Mahasiswa PGSD (Mawardi)

Song and Hill. (2007). A Conceptual Model for Under Standing Self-Directed Learning in Online Environments. Journal of interactive online learning, 6 (1).

Stewart, Rodney.A. (2007). Evaluating the self-directed learning readiness of engineering undergraduates: a necessary precursor to project-based learning. World transactions on engineering and technology education (C) 2007 UICEE. 6 (1), 59-62.

Surjono, H., D. (2010). Membangun Course e-learning berbasis Moodle. Yogyakarta: UNY Press

Smaldino, S.E., Lowther, D.L., Russell, J.D. ( $\left.{ }^{8} \mathrm{ed}\right) .(2005)$. Instructional technology and media for learning. New Jersey: Merrill Prentice Hall.

Undang-Undang Republik Indonesia Nomor 14 Tahun 2005 tentang Guru dan Dosen. Jakarta: Depdiknas.

Usta, Ertuğrul. (2011). The Examination Of Online Self-Regulated Learning Skills In Web-Based Learning Environments In Terms Of Different Variables. TOJET: The Turkish online journal of educational technology, 10 (3).

Zimmerman, B., J. (2008). Investigating Self-Regulation and Motivation: Historical Background, Methodological Developments, and Future Prospects. American Educational Research Journal, 45 (1), 166-183. 